\title{
Intensification of the inverted sugar syrup production using the rotor-pulsation processing
}

\author{
Oleksandr Obodovych ${ }^{1}$, Oleksandr Shevchenko ${ }^{2}$, Valerii Myronchuk ${ }^{2}$, \\ Anna Lymar', Vitalii Sydorenko', Roman Yakobchuk ${ }^{2}$
}

\section{1 - Institute of Engineering Thermophysics of NAS of Ukraine, Kyiv, Ukraine 2 - National University of Food Technologies, Kyiv, Ukraine}

\section{Keywords:}

Sugar

Syrup

Inversion

Rotor-pulsation

Article history:

Received

14.04.2021

Received in

revised form

26.08.2021

Accepted

30.09.2021

Corresponding author:

Vitalii Sydorenko

E-mail:

tdsittf@ukr.net

DOI:

$10.24263 / 2304-$

974X-2021-10-3-

13

\section{Abstract}

The aim of the work is to intensify the process of inverted sugar syrup production using the treatment of water-sugar solution in a rotor-pulsation apparatus.

Materials and methods. The aqueous solutions of chemically pure sucrose were used. The studies were conducted using a rotorpulsation apparatus in the range of flow shear rates from $20 \times 10^{3} \mathrm{~s}^{-1}$ to $50 \times 10^{3} \mathrm{~s}^{-1}$. Determination of carbohydrate content was carried out by high-performance liquid chromatography (HPLC).

Results and discussion. The increase in temperature, processing time, and decrease in $\mathrm{pH}$ value at a constant flow shear rate led to an increase of the amount of inverted sugar formed. Complete inversion of sucrose occured at a treatment of sugar solution at temperature of $80{ }^{\circ} \mathrm{C}, \mathrm{pH} 3.0$, and a flow shear rate of $20 \times 10^{3} \mathrm{~s}^{-1}$ for 30 minutes. At a flow rate of $50 \times 10^{3} \mathrm{~s}^{-1}$ almost all sucrose was hydrolyzed at $\mathrm{pH} 3.5$, and the duration of the process was just 5 minutes under conditions of five-time processing in the rotor-pulsation apparatus in the circulating mode.

In the syrup prepared by the proposed technology at a temperature of $70{ }^{\circ} \mathrm{C}$ and the duration of treatment 5 minutes, all sucrose in the solution was inverted, and no traces of hydroxymethylfurfural were detected.

It is assumed that critical stresses occur at the site of the sucrose chain, and the chemical covalent bonds are broken. The break of these bonds during the process of mechano-chemical destruction occurs on the weakest in terms of energy bonds. As a result of mechanochemical influence on the section of the sucrose chain $(\mathrm{C}-\mathrm{O}-\mathrm{C})$, there are critical stresses and the connection is broken. This leads to the formation of free radicals. One radical attaches to the $\mathrm{OH}^{-}$ion and another to the $\mathrm{H}^{+}$ion forming glucose and fructose.

Conclusions. The use of treatment of water-sugar solution in a rotor-pulsation apparatus by the proposed technology allows to intensify process of sugar inversion, namely, reduces the duration of the inversion from 120 to 5 minutes, and ensures almost complete inversion of sucrose excluding the formation of hydroxymethylfurfural. 


\section{Introduction}

Inverted sugar syrups, product of hydrolyzed sucrose, which contains instead of sucrose the mixture of glucose and fructose in ratio 1: 1, become a major sweetener and additive used extensively in the production of a wide variety of foods and beverages. Inverted sugar syrups have many advantages compared to sucrose that makes them attractive to food manufacturers. These include its sweetness, solubility, acidity, and its relative cheapness (Parker et al., 2010). Starch produced from corn, wheat, or barley due to enzymatic hydrolysis is converted into glucose, and then due to isomerization into inverted sugar syrup (Ermolaeva et al, 2012).

There are several ways to obtain inverted sugar syrup from sucrose, namely enzymatic hydrolysis (Mouelhi et al., 2014); hydrolysis by ion exchange (Khan et al., 1996), but the simplest and most common is the method of inverting sucrose by the treatment with citric acid. This method, however, has a number of disadvantages, namely the high process temperature $\left(80-100^{\circ} \mathrm{C}\right.$ ), long process duration (up to 2 hours), and most importantly, that this method allows to invert no more than $55 \%$ of sucrose due to increased accumulation of hydroxymethylfurfural (Vasilishina et al., 1986).

The task is to increase the yield of inverted sugar by using additional methods of the inversion process.

In the food industry, rotor-pulsation apparatus (high-shear mixers) are used to create emulsions with both high and low viscosity such as salad dressings, sauces, cottage cheese, fruit, vegetable and sour milk desserts, purees, and cream. Rotor-pulsation apparatus are also used for dispersing artificial sweeteners, and cloud agents in carbonated soft drinks, for blending miscible liquids of very different viscosities, to deagglomerate and uniformly disperse nanoparticles in liquids, and also to suspend fine air bubbles (e.g., ice cream) (Rodgers et al., 2016).

The physical effects of rotor-pulsation apparatus have been studied by many authors. For example, in (Avdeeva et al., 2011) the influence of hydrodynamic cavitation on the production of phospholipid nanostructures was studied.

The influence of alternating impulses of pressure occurring in the rotor-pulsation apparatus on liquid binary systems such as water systems and water-ethanol mixtures was studied in (Dubovkina, 2017).

Under the influence of alternating impulses of pressure, the quantity of the dissolved oxygen in the water and water-ethanol mixtures in comparison with the initial maintenance decreased practically by $50-55 \%$.

Studies (Dubovkina, 2017a) of hydrodynamic oscillations generated to activate the hydrated lime suspension for beet juice treatment have shown an increase in the hydrogen potential of the hydrated lime suspension by $15 \%$.

Intensification of the process of inverted sugar syrup production can be achieved by including of the rotor-pulsation apparatus in the appropriate technological scheme (Myronchuk et al., 2019).

Therefore, there is a need to study the influence of physicochemical effects that occur during the processing of glucose-fructose syrups in a rotor-pulsation apparatus on the intensity of sucrose inversion.

The main technological parameters of the sucrose inversion process are temperature, $\mathrm{pH}$ of the solution, and the process duration. Given the fact that the proposed technological scheme includes the processing of syrup in a rotor-pulsation apparatus, it is advisable to enter another parameter influenced on the intensity of the hydrolysis process. This parameter is the 
shear flow rate $\gamma, \mathrm{s}^{-1}$, in the gap between the rotor and the stator of the rotor-pulsation apparatus (Dolinskij et al., 1998; 1999; 1999a).

The aim of this work was to intensify the technology of inverted sugar syrup production from sucrose using the treatment of water-sugar solution in a rotor-pulsation apparatus.

\section{Materials and methods}

The object of study was the process of inverted sugar syrup production. The subject of research was determination of the effect of flow rate in the rotary pulsation apparatus on the inversion of sucrose in aqueous solutions of sucrose.

\section{Experimental instalation}

Experimental studies of this process were conducted on a specially created pilot plant, the scheme of which is presented in Figure 1. The volume of the sugar syrup vessel was 100 liters. The productivity of the rotor-pulsation apparatus (RPA) was $6 \mathrm{~m}^{3} / \mathrm{h}$.

The rotor-pulsation apparatus consists of two coaxial cylinders namely a fixed stator and a movable rotor with radial channels in the side walls of different cross- sections (Fig. 2) (Zhang et al., 2012). The substance to be treated is fed into the rotor cavity, through the channels passes into the inter-cylinder gap, and subsequently through the stator channels.

The shear rate of the flow was regulated by changing the speed of the rotor shaft using a frequency converter.

The range of flow shear rates was from $20 \times 10^{3} \mathrm{~s}^{-1}$ to $50 \times 10^{3} \mathrm{~s}^{-1}$.

During the studies, the dependence of sucrose inversion on temperature, $\mathrm{pH}$ and process duration was determined at a constant flow shear rate, which was $20 \times 10^{3} \mathrm{~s}^{-1}$. The amount of inverted sugar formation was determined depending on the flow shear rate, $\mathrm{pH}$ and process duration at a temperature of $70^{\circ} \mathrm{C}$.

Technological operations were performed in the following order. In the sugar syrup vessel 3 , the sugar was mixed with water to a dry matter concentration of $65 \%$. In citric acid solution preparation vessel 1, a $25 \%$ solution of citric acid was prepared and added to the sugar syrup vessel 3 in an amount of $0.75 \mathrm{~kg}$ of citric acid per $100 \mathrm{~kg}$ of sugar.

This solution was treated in a rotor-pulsation apparatus in a recirculation mode until complete hydrolysis of sucrose was occurred, and then sent for cooling and storage. The dry matter content in inverted glucose-fructose syrup was about $65 \%$.

\section{Determination of carbohydrates}

Determination of carbohydrates content was carried out by high-performance liquid chromatography (HPLC) (Costa et al., 2015).

An Agilent 1100 chromatograph with a diode array detector was used in this study. UV detection was performed at $195 \mathrm{~nm}$ at a column temperature of $30^{\circ} \mathrm{C}$ and a column with the aminopropyl stationary phase (Zorbax Carbohydrate $250 \times 4.6 \mathrm{~mm}, 5 \mu \mathrm{m}$, manufactured by Agilent). The ratio of acetonitrile used and deionized water was from 82 to $18 \%$ vol.

\section{Determination of $\mathrm{pH}$ value}

To determine the degree of activity of hydrogen ions in the liquid used a $\mathrm{pH}$ meter Ezodo 5011. 


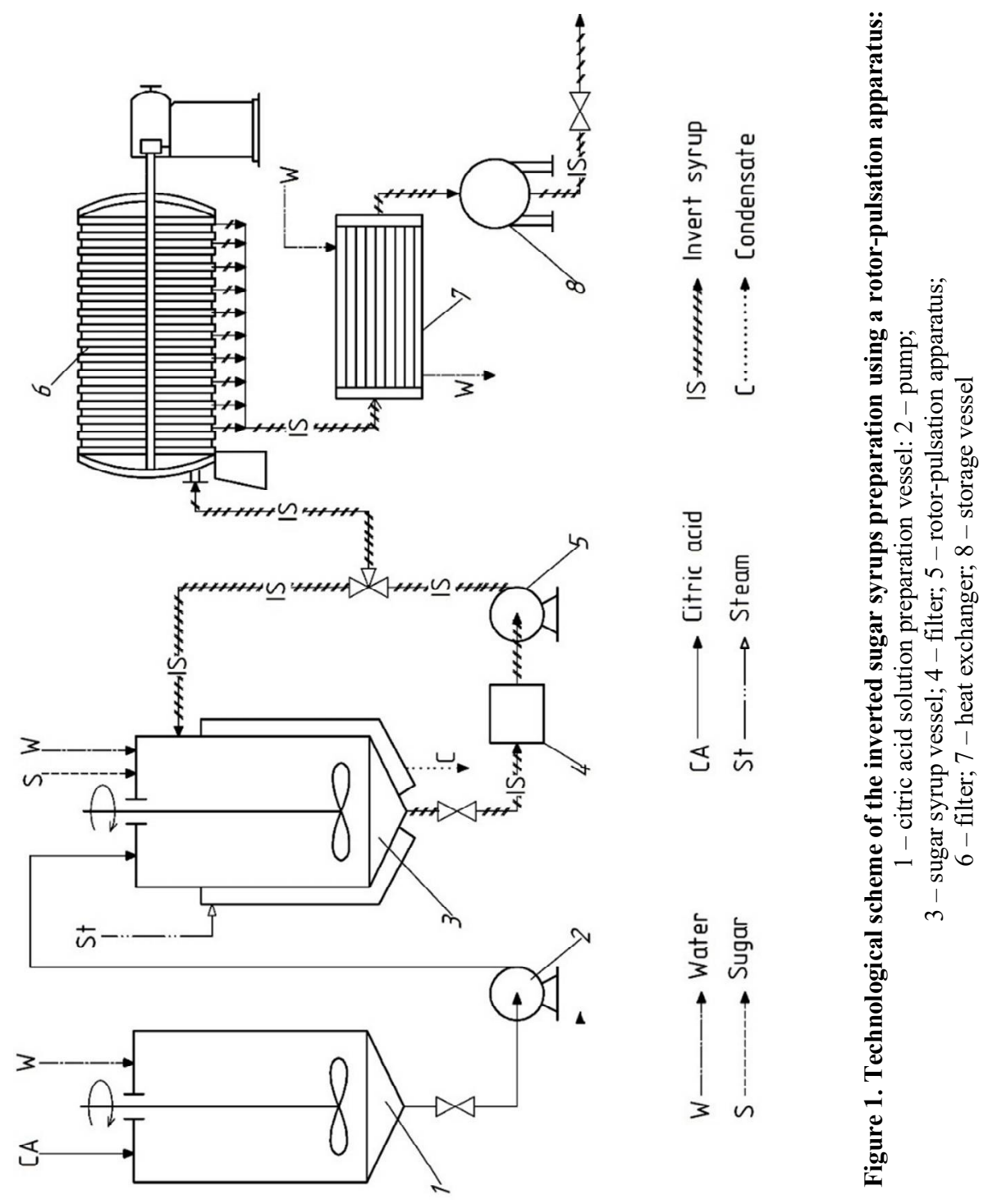




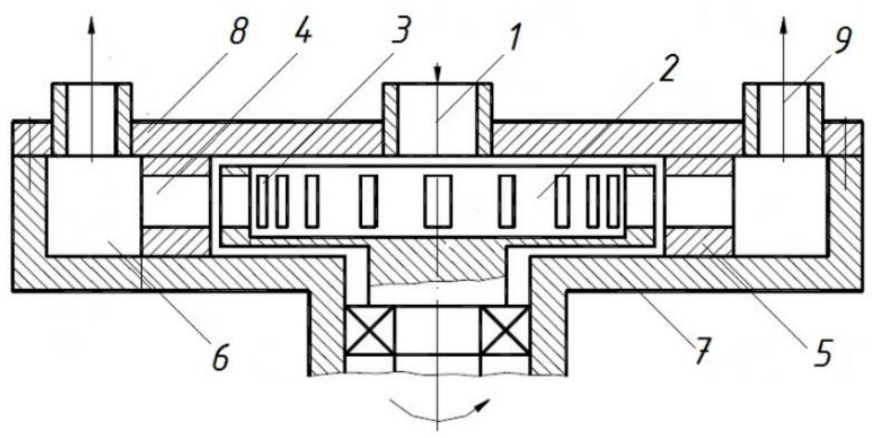

Figure 2. The design of rotor-pulsation apparatus:

1 - outlet; 2 - rotor; 3 - channels in the rotor; 4 - channels in the stator; 5 - stator; 6 - sound camera; 7 - housing; 8 - cover; 9 - inlet pipe.

\section{Results and discussion}

Dependence of the formation of inverted sugar on the temperature, $\mathrm{pH}$, and duration of the process at a shear rate of $20 \times 10^{3} \mathrm{~s}^{-1}$

The dependence of the inverted sugar formation on the temperature, $\mathrm{pH}$, and the process duration at a flow shear rate of $20 \times 10^{3} \mathrm{~s}^{-1}$ is shown in Table 1. It was determined that with the process duration increasing from 30 to 120 minutes at a flow shear rate of $20 \times 10^{3} \mathrm{~s}^{-1}$, the amount of the formed inverted sugar increased from 43 to $46 \%$ at $\mathrm{pH}=4.0$; from 51 to $57 \%$ at $\mathrm{pH}=3.5$; from 61 to $66 \%$ at $\mathrm{pH}=3.0$; from 69 to $71 \%$ at $\mathrm{pH}=2.5$ at a temperature of 50 ${ }^{\circ} \mathrm{C}$. Increasing the temperature to $80^{\circ} \mathrm{C}$ led to the fact that with increasing process duration from 30 to 120 minutes at a flow shear rate of $20 \times 10^{3} \mathrm{~s}^{-1}$ the amount of the formed inverted sugar increased from 53 to $58 \%$ at $\mathrm{pH}=4.0$; from 72 to $75 \%$ at $\mathrm{pH}=3.5$; from 98 to $100 \%$ at $\mathrm{pH}=3.0$. Increasing the temperature to $90{ }^{\circ} \mathrm{C}$ led to the fact that with increasing process duration from 30 to 120 minutes at a flow shear rate of $20 \times 10^{3} \mathrm{~s}^{-1}$ the amount of the formed inverted sugar increased from 98 to $100 \%$ at $\mathrm{pH} 4.0$.

\section{Dependence of the inverted sugar formation on the flow shear rate, $\mathrm{pH}$, and the process duration at a constant temperature of $70^{\circ} \mathrm{C}$}

The dependence of the inverted sugar formation on the flow shear rate, $\mathrm{pH}$, and the process duration at a constant temperature of $70{ }^{\circ} \mathrm{C}$ is given in Table 2 .

It was determined that with increasing of the process duration from 5 to 20 minutes at the flow shear rate of $30 \times 10^{3} \mathrm{~s}^{-1}$ the amount of inverted sugar increased from 65 to $73 \%$; at a shear rate of the flow of $40 \times 10^{3} \mathrm{~s}^{-1}$ from 75 to $85 \%$; at a flow shear rate of $50 \times 10^{3} \mathrm{~s}^{-1}$ from 87 to $93 \%$. It was determined that with increasing the process duration from 5 to 20 minutes at the flow shear rate of $30 \times 10^{3} \mathrm{~s}^{-1}$ the amount of inverted sugar increased from 65 to $73 \%$; at a flow shear rate of $40 \times 10^{3} \mathrm{~s}^{-1}$ from 75 to $85 \%$; at a flow shear rate of $50 \times 10^{3} \mathrm{~s}^{-1}$ from 87 to $93 \%$. Reducing the $\mathrm{pH}$ to 3.5 , depending on the process duration from 5 to 20 minutes at a flow shear rate of $30 \times 10^{3} \mathrm{~s}^{-1}$, amount of the inverted sugar increased from 74 to $81 \%$; at a flow shear rate of $40 \times 10^{3} \mathrm{~s}^{-1}$ from 89 to $96 \%$; at a flow shear rate of $50 \times 10^{3} \mathrm{~s}^{-1}$ almost all sucrose was hydrolyzed in 5 minutes of processing (Patent UA 9399. A method of preparing inverted sugar syrup). 
Table 1

Formation of inverted sugar depending on the temperature, $\mathrm{pH}$ and the process duration at a flow shear rate of $20 \times 10^{3} \mathrm{~s}^{-1}$

\begin{tabular}{|c|c|c|c|}
\hline$t,{ }^{\circ} \mathrm{C}$ & pH & Process duration, min & Amount of inverted sugar, $\%$ \\
\hline \multirow{12}{*}{50} & \multirow{3}{*}{4.0} & 30 & 43 \\
\hline & & 60 & 45 \\
\hline & & 120 & 46 \\
\hline & \multirow{3}{*}{3.5} & 30 & 51 \\
\hline & & 60 & 55 \\
\hline & & 120 & 57 \\
\hline & \multirow{3}{*}{3.0} & 30 & 61 \\
\hline & & 60 & 65 \\
\hline & & 120 & 66 \\
\hline & \multirow{3}{*}{2.5} & 30 & 69 \\
\hline & & 60 & 71 \\
\hline & & 120 & 71 \\
\hline \multirow{9}{*}{80} & \multirow{3}{*}{4.0} & 30 & 53 \\
\hline & & 60 & 57 \\
\hline & & 120 & 58 \\
\hline & \multirow{3}{*}{3.5} & 30 & 72 \\
\hline & & 60 & 74 \\
\hline & & 120 & 75 \\
\hline & \multirow{3}{*}{3.0} & 30 & 98 \\
\hline & & 60 & 99 \\
\hline & & 120 & 100 \\
\hline \multirow{3}{*}{90} & \multirow{3}{*}{4.0} & 30 & 98 \\
\hline & & 60 & 100 \\
\hline & & 120 & 100 \\
\hline
\end{tabular}

Table 2

Formation of inverted sugar depending on the flow rate, $\mathrm{pH}$ and the process duration at a temperature of $70{ }^{\circ} \mathrm{C}$

\begin{tabular}{|c|c|c|c|}
\hline pH & Process duration, min & $\gamma, \times 10^{3} \mathrm{~s}^{-1}$ & Amount of inverted sugar, $\%$ \\
\hline \multirow{9}{*}{40} & 5 & \multirow{3}{*}{30} & 65 \\
\hline & 10 & & 71 \\
\hline & 20 & & 73 \\
\hline & 5 & \multirow{3}{*}{40} & 75 \\
\hline & 10 & & 83 \\
\hline & 20 & & 85 \\
\hline & \multirow[t]{3}{*}{ r } & \multirow{3}{*}{50} & 97 \\
\hline & & & 91 \\
\hline & & & 92 \\
\hline \multirow{9}{*}{3.5} & 5 & \multirow{3}{*}{30} & 74 \\
\hline & 10 & & 79 \\
\hline & 20 & & 81 \\
\hline & 5 & \multirow{3}{*}{40} & 89 \\
\hline & 10 & & 94 \\
\hline & 20 & & 96 \\
\hline & 5 & \multirow{3}{*}{50} & 100 \\
\hline & 10 & & 100 \\
\hline & 20 & & 100 \\
\hline
\end{tabular}


The traditional technology of the acid inversion of sucrose is accompanied by the formation of a toxic by-product of the deep decomposition of sucrose hydroxymitylfurfural. This is due to the long duration and the high temperature of treatment. The use of rotorpulsation apparatus in the process of inverted sugar syrup production eliminates the formation of hydroxymethylfurfural due to reducing the inversion process duration to 5 minutes.

\section{Determination of the composition of inverted sugar syrup depending on the processing method}

The characteristics of inverted sugar syrup prepared according to the existing and proposed technology are presented in Table 3.

Characteristics of inverted sugar syrup obtained in the traditional way

Table 3 and using a rotor-pulsation apparatus

\begin{tabular}{|c|c|c|c|}
\hline Method of treatment & $\begin{array}{c}\text { Duration, } \\
\text { min }\end{array}$ & $\begin{array}{c}\text { Amount of } \\
\text { inverted sugar, } \\
\text { \% }\end{array}$ & $\begin{array}{c}\text { Content of } \\
\text { hydroxymethylfurfural, } \\
\text { mg/1000 g of syrup }\end{array}$ \\
\hline $\begin{array}{l}90^{\circ} \mathrm{C} \text {, without treatment in } \\
\text { a potor-puslation apparatus }\end{array}$ & 120 & 55 & 0.09 \\
\hline $\begin{array}{l}70^{\circ} \mathrm{C}, \text { with treatment in a } \\
\text { potor-puslation apparatus }\end{array}$ & 5 & 100 & - \\
\hline
\end{tabular}

The results indicate that application of proposed technology for production of inverted sugar syrup reduces the process duration from $120 \mathrm{~min}$ to $5 \mathrm{~min}$, ensures almost complete hydrolysis of sucrose, and increases the amount of inverted sugar in solution from 55 to $100 \%$ without the formation of hydroxymethylfurfural.

Effect of the inversion duration on the composition of sugars at a temperature of $70^{\circ} \mathrm{C}$, pH 3.5 and the flow rate of $50 \times 10^{3} \mathrm{~s}^{-1}$

Figure 3 shows the results of studies of the effect of the inversion duration on the composition of sugars at a temperature of $70^{\circ} \mathrm{C}, \mathrm{pH} 3.5$ and a shear flow rate of $50 \times 10^{3} \mathrm{~s}^{-1}$.

Effect of the number of processing cycles in the rotary pulsation apparatus on the degree of sucrose inversion.

Results shown in Figure 4 indicate that complete inversion of sucrose was achieved by five times treatment in a rotor-pulsation apparatus in a circulating mode for 5 minutes at a temperature of $70{ }^{\circ} \mathrm{C}, \mathrm{pH} 3.5$ and shear flow rate of $50 \times 10^{3} \mathrm{~s}^{-1}$. 


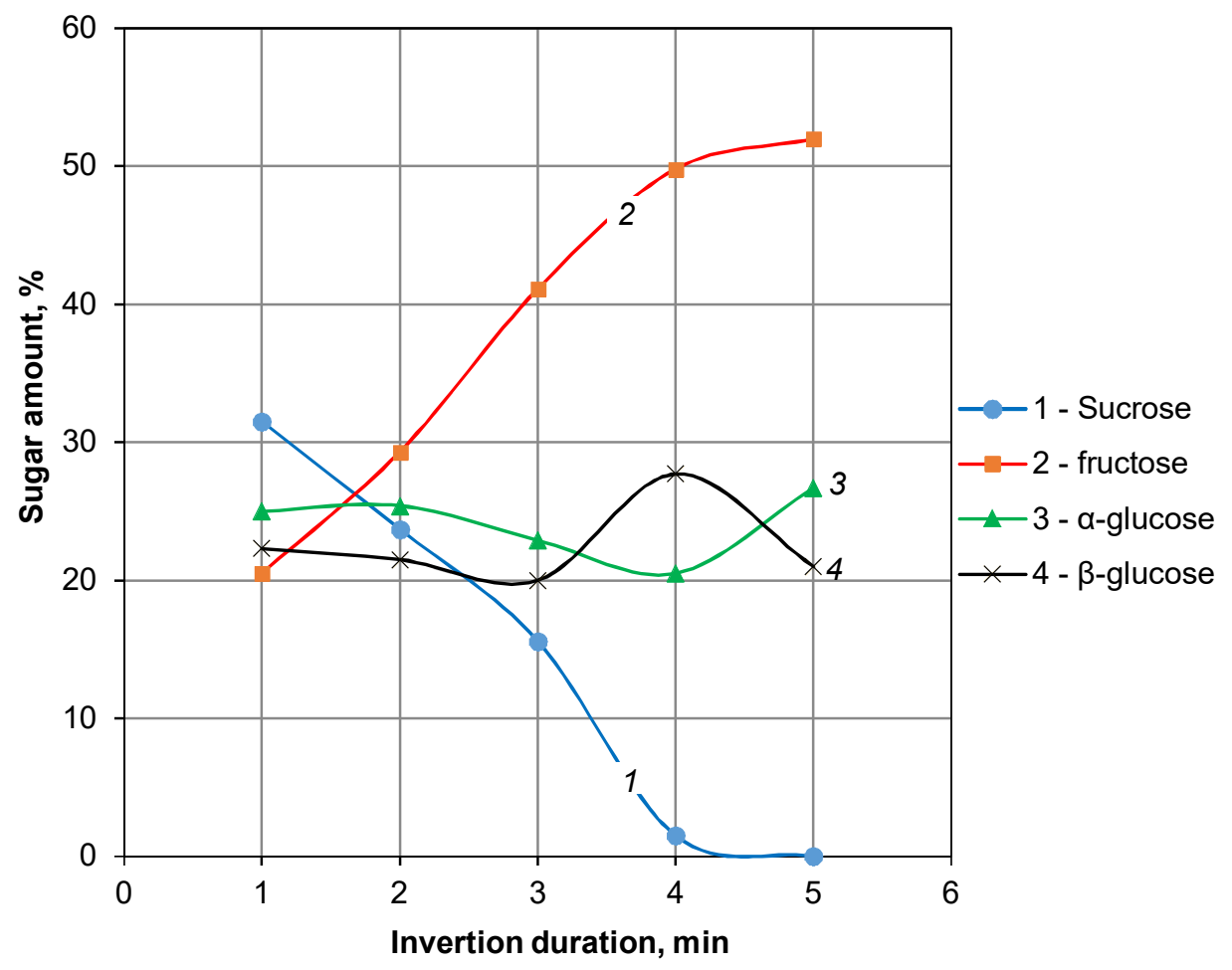

Figure 3. Production of sugars depending on the inversion duration at a temperature of $70^{\circ} \mathrm{C}$, $\mathrm{pH} 3.5$ and a shear flow rate of $50 \times 10^{3} \mathrm{~s}^{-1}$

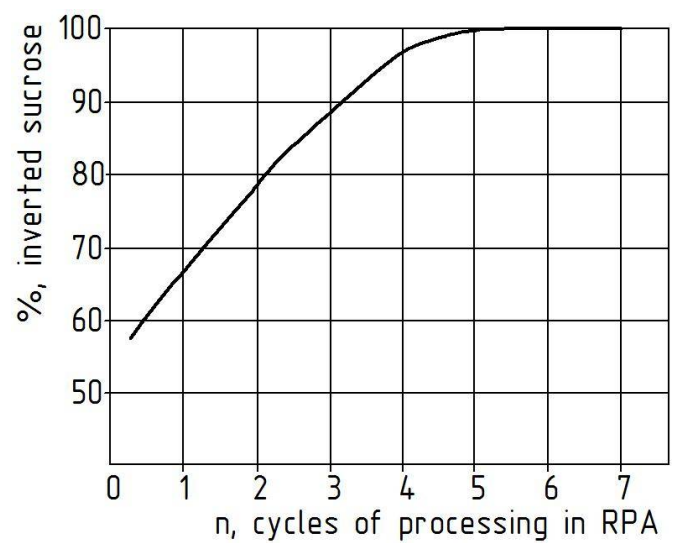

Figure 4. Amount of inverted sucrose depending on the number of cycles of glucosefruit syrup processing in a rotor-pulsation apparatus 
Therefore, the intensive inversion of sucrose using of rotor-pulsation treatment causes destruction of an acetal bond (an acetal oxygen bridge) $(\mathrm{C}-\mathrm{O}-\mathrm{C}$ ) which joins glucose and fructose units in molecule of sucrose due to the simultaneous action of chemical and physical influences. The breaking energy of this bond is $1076 \mathrm{~kJ} / \mathrm{mol}$.

Critical stresses occur at the site of the sucrose chain and chemical covalent bonds are broken. The break of these bonds in the process of mechano-chemical influence occurs on the weakest in terms of energy bonds. In the case of mechanically activated hydrolysis, the destruction of the chains is localized at heterogeneous bonds, and in this respect, such processes do not differ from the corresponding purely chemical ones.

The breakdown of the sucrose chain usually follows the acetal bonds, but under certain conditions of the process, there is a breaking of carbon (C-C) bonds (Stick, 2001).

Action of citric acid weakens the $(\mathrm{C}-\mathrm{O})$ bond in sucrose and allows implementing a mechanically activated chemical process. Because of mechano-chemical influence on the section of the sucrose chain $(\mathrm{C}-\mathrm{O}-\mathrm{C})$ there are critical stresses and the connection is broken. This leads to the formation of free radicals. One radical attaches the $\mathrm{OH}^{-}$ion and another to $\mathrm{H}^{+}$ion As a result, the process of production of inverted sugar is intensified, i.e., the formation of a mixture of monosaccharides of glucose and fructose.

It is important that the proposed technology has significant advantages in terms of energy and resource saving characteristics (Dolinskiy et al., 2012).

\section{Conclusion}

The use of circulating five-time rotor-pulsation treatment of water-sugar solution in the circulating mode in the technology of inverted sugar syrups production at a temperature of $70{ }^{\circ} \mathrm{C}, \mathrm{pH} 3.5$ and a flow rate of $50 \times 10^{3} \mathrm{~s}^{-1}$ allows intensifying this process, namely:

- Reduce the duration of inversion to 5 minutes;

- Increase the amount of inverted sucrose from $55 \%$ to almost complete inversion;

- Exclude the formation of hydroxymethylfurfural.

\section{References}

Avdeeva L.Yu., Ivanitskiy G.K. (2011), Using of hydrodynamical cavitation in technologies of phospholipid nanostructure technologies, Modern Science: Researches, Ideas, Results, 2(7), pp. 59-65.

Balabudkin M.A. (1983), Rotorno-pul'sacionnye apparaty $v$ himiko-farmacevticheskoj promyshlennosti, Medicina, Moscow.

Costa M., Conte-Junior C.A. (2015), Chromatographic methods for the determination of carbohydrates and organic acids in foods of animal origin, Comprehensive Reviews in Food Science and Food Safety, 14(5), pp. 586-600, DOI: 10.1111/1541-4337.12148

Dolinskij A.A., Basok B.I. (1998), Rotorno-pul'sacionnyj aparat. Soobshhenija 1. Promyshlennaja teplotehnika, 6. pp. 7-10.

Dolinskij A.A., Basok B.I. (1999), Rotorno-pul'sacionnyj aparat. Soobshhenija 2. Promyshlennaja teplotehnika, 1, pp. 3-5.

Dolinskij A.A., Basok B.I. (1999a), Rotorno-pul'sacionnyj aparat. Soobshhenija 3. Promyshlennaja teplotehnika, 2, 3, pp. 3-5.

Dolinskiy A.A., Obodovich A.N., Borhalenko Yu.A. (2012), Metod diskretno-impulsnogo vvoda energii i ego realizatsiya, Apostrof, Kharkiv. 
Dubovkina I. (2017), Change of physical and chemical parameters of the liquid binary systems by alternating impulses of pressure, Ukrainian Food Journal, 6(1), pp. 142153, DOI: $10.24263 / 2304-974 X-2017-6-1-16$

Dubovkina I. (2017a), Application of hydrodynamic oscillations for activation of the hydrated lime slurry, Ukrainian Food Journal, 6(4), pp. 717-726, DOI: 10.24263/2304974X-2017-6-4-11

Ermolaeva G.A., Sapronova L.A., Krivovoz B.G. (2012), Sahar i ego zameniteli v proizvodstve produktov pitaniya, Pischevaya promyishlennost, 6, pp. 48-51

Khan S. H., Rahman K. (1996), Inversion of sucrose solution by ion exchange: evaluation of reaction rate and diffusivity, The Chemical Engineering Journal and the Biochemical Engineering Journal, 61(1), pp. 7-12, DOI: 10.1016/0923-0467(96)02978-8

Mouelhi R., Abidi F, Galai S, Marzouki N.M. (2014), Immobilized Sclerotinia sclerotiorum invertedase to produce inverted sugar syrup from industrial beet molasses by product, World Journal of Microbiology and Biotechnology, 30, pp. 1063-1073, DOI: $10.1007 / \mathrm{s} 11274-013-1525-8$

Myronchuk V., Obodovych O., Sydorenko V. (2019), The influence of discrete-pulsed energy input on the distribution of plant biomass, Ukrainian Food Journal, 8(3), pp. 634-645, DOI: DOI: $10.24263 / 2304-974 x-2019-8-3-17$

Parker K., Salas M. and Veronica C. Nwosu V. (2010), High fructose corn syrup: Production, uses and public health concerns. Biotechnology and Molecular Biology Review, 5(5), pp. 71-78, DOI: 10.5897/BMBR2010.0009

Rodgers T., Trinh L. (2016), High-Shear Mixing: Applications in the Food Industry, Available at: DOI: 10.1016/B978-0-08-100596-5.03095-X

Stick R.V. (2001), Carbohydrates: The Sweet Molecules of Life, Academic Press.

Vasilishina M.S., Bondareva E.S. (1986), Opredelenie oksimetilfurfurola v invertedirovannyh saharnyh siropah, Pishhevaja promyshlennost', 6, pp.86-88.

Zhang J., Xu S., Li W., (2012), High shear mixers: A review of typical applications and studies on power draw, flow pattern, energy dissipation and transfer properties, Chemical Engineering and Processing: Process Intensification, 57-58, pp. 25-41, DOI: 10.1016/j.cep.2012.04.004 